Instructions for authors, subscriptions and further details:

http://ijrs.hipatiapress.com

\title{
Participation in paid employment among the Finnish Roma
}

Simo Mannila ${ }^{1}$, Anu E Castaneda ${ }^{2}$, Marianne Laalo ${ }^{2}$ and Hannamaria Kuusio ${ }^{2}$

1) University of Helsinki, Finland

2) Finnish Institute for Health and Welfare, Finland

Date of publication: March $15^{\text {th }}, 2021$

Edition period: March 2021 - July 2021

To cite this article: Mannila, S., Castaneda, A. E., Laalo, M., \& Kuusio, H. (2021). Participation in paid employment among the Finnish Roma. International Journal of Roma Studies, 3(1), 1-23. doi:

10.17583/ijrs.2021.6973

To link this article: http://dx.doi.org/10.17583/ijrs.2021.6973

\section{PLEASE SCROLL DOWN FOR ARTICLE}

The terms and conditions of use are related to the Open Journal System and to Creative Commons Attribution License (CCAL). 


\section{Participation in paid employment among the Finnish Roma}

Simo Mannila

University of Helsinki

Anu E Castaneda

Finnish Institute for Health

and Welfare
Marianne Laalo

Finnish Institute for Health

and Welfare

Hannamaria Kuusio

Finnish Institute for Health

and Welfare

\section{Abstract}

The article describes participation in paid work among Finnish Roma, based on data gathered by face-to-face interviews for the Finnish Roma Participation and Wellbeing Study $(n=234))$. We wanted to assess the relevance of some explanatory factors for the low paid work rate of the Roma, found in countries with a significant Roma minority, in the light of new material from Finland where the Roma minority is small and rather homogeneous. No earlier studies on their participation in paid work in Finland exist.

The research shows the importance of education to finding paid employment, in compliance with earlier international results. Living in Roma culture has a negative association with participation in paid employment. We were not able to assess discrimination at recruitment, obviously the key phase for successful or unsuccessful integration of the Roma in the Finnish labour market. Unlike in many countries, in Finland there was no significant difference in the paid employment rate of Roma men and women.

Keywords: Employment, Education, Discrimination. Roma Culture, Finland 


\section{Participación en el empleo remunerado entre los romaníes finlandeses}

Simo Mannila

University of Helsinki

Anu E Castaneda

Finnish Institute for Health

and Welfare
Marianne Laalo

Finnish Institute for Health

and Welfare

Hannamaria Kuusio

Finnish Institute for Health

and Welfare

\section{Resumen}

El artículo describe la participación de los romaníes finlandeses en el empleo remunerado, según los datos recopilados mediante entrevistas personales para el Estudio de Participación y Bienestar de Romaníes Finlandeses $(\mathrm{m}=80$, f = 143). Queríamos evaluar la relevancia de algunos factores que explican la baja tasa de empleo remunerado de los romaníes, los cuales se encuentran en países con una minoría romaní significativa, a la luz del material de Finlandia, donde la minoría romaní es pequeña y homogénea. No existen estudios anteriores sobre su participación en el trabajo remunerado en Finlandia.

La investigación muestra la importancia de la educación para encontrar un empleo remunerado, de acuerdo con los resultados anteriores internacionales. La adhesión a la cultura romaní está interrelacionada con problemas en la participación en el empleo remunerado. No pudimos evaluar la discriminación en la contratación, obviamente la fase clave para la inclusión de los romaníes en el mercado laboral finlandés. A diferencia de muchos países, en Finlandia no hubo una diferencia significativa en la tasa de empleo remunerado de hombres y mujeres romaníes.

Palabras clave: Empleo, Educación, Discriminación, Cultura Gitana, Finlandia. 


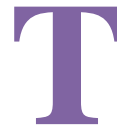

he paid employment rate of the Roma is generally low, although there is major variation between European countries. In Italy and $10 \%$, while in Bulgaria, Hungary and Czech Republic the employment rates were around $30 \%$. In some cases, the Roma population has a rather high self-employment rate, for instance $20-25 \%$ in France, Greece and Italy (FRA, 2012). The Roma are in general 2-6 times more likely to have irregular work - and self-employment is often irregular, too - than their non-Roma neighbours (Council of Europe, 2012; Robayo-Abril \& Millán, 2019) Irregular work interrelates strongly with labour market vulnerability and a higher risk of poverty. (e.g. Frazer, Gutiérrez \& Peña-Casas, 2011)

According to FRA surveys there has been no important progress during the past few years on Roma employment in nine CEE countries. Approximately one in four Roma aged 16+ years was employed or selfemployed, while the comparable figure for non-Roma in the EU was $64 \%$. One third of the surveyed Roma told that they were unemployed, with particularly high shares of unemployment in Croatia, Spain and Bulgaria. Looking at paid work experience from the past four weeks, the paid employment rate for Roma was $43 \%$, while the corresponding share was $70 \%$ for non-Roma in the surveyed countries, and again, with a major gender gap among the Roma (FRA, 2018b; 2019). Altogether 34\% of Roma men, but only $16 \%$ of Roma women were at work (FRA, 2018b; 2019). Similar results are found in country-specific surveys: for instance, in Croatia, 25\% of Roma men and 58\% of Roma women had never been in (paid) work (Kunac, Klasnić \& Lalić 2018).

Judging by this information, the EU Framework target cutting the employment gap between Roma and the rest of the population until 2020 has been very difficult to achieve. Ethnic discrimination and incoherence of the policy mix aimed at supporting the Roma inclusion are mostly regarded as key problems of the Roma in modern labour market. (E.g. FRA, 2018a; Petrova, 2004; Rosenfield, 2010; Ram, 2014)

Besides ethnic discrimination and incoherent public support, Messing (2014a) has identified several other causes behind the low employment rates of the Roma minority. They include: 
- Low level of education due to systemic factors (e.g. institutional segregation, variations in educational quality) and institutional factors (schools' and teachers' approach to ethnic diversity, prejudices, teaching practices);

- Structures of national economies i.e. changing demand of various types of workforce and corresponding qualifications;

- Employers' general costs depending of the wage and salary levels, payroll taxes etc.

- Linked with the costs of employment the exclusion of the Roma from formal employment into informal work; this kind of work is typically irregular and unstable, includes activities that often are not considered employment (e.g. collecting and trading with goods, waste recycling), and sometimes the activities are defined illegal;

- Economic downturns hit marginal labour market groups, such as the Roma, worse than others.

However, most Roma research has been carried out in the Balkan states or other countries with a significant Roma minority. There is rather little research into the employment of Roma elsewhere, for instance, in Nordic countries, where the Roma minority is rather small. The EU countries also differ somewhat by national labour markets and welfare regimes (EspingAndersen, 1990; 1996). In this article, we discuss the validity of the above general findings concerning Roma in the labour market in the light of recent Finnish data.

\section{Roma minority in Finland}

The Roma minority in Finland has lived in Finland centuries and its size has been estimated to be around 10.000 , a more exact figure is not known, since Finnish population registers do not contain information on ethnicity (Finnish Ministry of Social Affairs and Health, 2004). Roma immigration to Finland from the new EU Member States has been very limited and the Roma immigrants are not addressed in this article. Finland has pioneered in establishing cooperation structures between the state and the Roma minority as well as founding Roma NGOs. For instance, the Advisory Board of Romani Affairs was established in 1956 and at the late 1960s the 
first Roma NGOs focusing on advocacy were founded (LähteenmäkiSmith, 2011). Finnish Roma policies are often considered successful, which is largely based on positive discrimination measures in housing in 1970s and 1980s and their results. Today, the Finnish Roma not only live in the same areas than the majority Finns but also wish to "live well" according to majority populations' norms. This means preferring to live in settled contemporary housing with nuclear families, further away from rest of their kin, and to work from 'nine until five' in the waged labour market (Berlin, 2015). However, there is also criticism concerning the Finnish approach towards national minorities Sámi and Roma (Keskinen, 2019) and policies based today largely on temporary funding from the European Social Fund (Granqvist, 2020).

In Finland, there is no geographical segregation of the Roma, who live practically in all municipalities across the country, neither is there segregation at local level. There has been special focus on Roma in Finland in the field of education and training, as well as in housing, considered some of the key problems of the Finnish Roma minority. There is no segregated education in Finland, however, similarly to Messing's findings, there are institutional problems leading to discriminatory behaviour against the Roma from the part of teachers or pupils in the general school system. In Finland, the majority of adult Roma (54\%) had been discriminated or harassed, if not systematically, at school, and Roma pupils have tended to drop off school more often than non-Roma ones (Rajala, Salonen, Blomerus \& Nissilä, 2011; Rajala \& Blomerus, 2015). However, until now there has been no data to compare the education and training level of the Finnish Roma minority with that of non-Roma Finnish population.

The housing conditions of the Finnish Roma have traditionally been worse than those of the non-Roma, due to discrimination in the housing market some challenges set by the Roma culture (Paulus, 1996; Vesanen, 1999; Törmä \& Huotari, 2018). Today, rental housing is most typical among the Finnish Roma, and public (municipal) housing seems to have a very important role for them, while the share of home-owners is much lower than among the Finnish population in general (Weiste-Paakkanen, Lämsä \& Kuusio, 2018).

One of the key factors most certainly bearing an impact on Roma employment in Finland, too, is the changing demand and supply of 
workforce. In the course of socio-economic change, some skills and professions turn obsolete or marginal, while new skills and professions emerge. In 1954, 78\% of adult Finnish Roma had an occupation, and the remaining $22 \%$ consisted of people, whose skills were unknown but who, nevertheless, might have had an occupation. The most common ones were various types of handicraft (29\%) and horse trade (17\%), while 14\% were unskilled workers (Tervonen, 2014, 177; cf. Clark, 2002).

There is no corresponding actual information available the professions of the Roma in Finland. Traditional horse trade has vanished due to changed agriculture and the demand for unskilled work is low in Finland as in most EU countries. Due to industrialization and globalization, traditional handicraft - Roma or non-Roma - has today a minor role in economy in Finland similarly to all developed countries. Having an occupation does not necessarily mean that you have paid work. Roma work diversely in all professional fields - for instance as cooks, flight attendants, nurses, athletes, journalists, and so on. The most popular fields of labour market training have been social welfare and healthcare, teacher training for teachers of Romani, training for youth instructors, information technology and music (Finnish Ministry of Social Affairs and Health, 2004). Since the 1960, when Roma musicians got a chance to record in Finland, they have been very successful in the national music scene (Kurkela, 2003).

Messing's comment on informality and irregularity and some of the work Roma do is very relevant for researching Roma employment and its true scope. ILO (1993) defines paid employment jobs as 'those jobs where the incumbents hold explicit (written or oral) or implicit employment contracts which give them a basic remuneration which is not directly dependent upon the revenue of the unit for which they work. This unit can be a corporation, a non-profit institution, a government unit or a household. Persons in paid employment jobs are typically remunerated by wages and salaries, but may be paid by commission from sales, from piece-rates, bonuses or in-kind payments such as food.' Today, our societies lay a strong emphasis on monetary remuneration, in-kind payments are rare, barter economy considered a feature of developing economies. Informal trading or exchange of goods and services between individuals and families is not paid work according to common understanding, but it may be important for some social groups or families. Finnish research, too, has 
shown the significance of relatives', friends' and neighbours' assistance for everyday life for groups living at the labour market margins; assistance, based on mutual trust, can be reciprocal not requiring immediate remuneration (e.g. Vähätalo, 1998; Saaritsa, 2008). Here we must make a reservation in compliance with Messing: our common understanding of paid work may exclude some of the work Roma people do, and, analogously, it may be difficult to capture the full range of Roma work when using survey data, based on self-assessment.

There is no specific information concerning employers' costs in hiring Roma jobseekers in Finland. Neither is there information concerning the situation of the Roma during economic downturns. We may expect that due to the present anti-discrimination legislation, the situation of the working Roma would not differ remarkably from that of the non-Roma during layoffs. The situation looks very different if we look at recruitment. There is a great deal of evidence from negative attitudes and discrimination towards the Roma minority in Finland. According to Joronen and Kruskopf (2014), $69 \%$ of the surveyed Roma had experienced discrimination during the past 12 months. The figure is considerably higher than that for other ethnic minorities in Finland. Other research points out similar problems (e.g. Nordberg, 2005; Anttonen, 2008; Syrjä and Valtakari, 2008). Altogether, $74 \%$ of the respondents consider being a Roma a disadvantage in recruiting in Finland, while the corresponding figure for the EU28 is 38\%. (European Commission, 2019) In the campaign 'Työnimi' (Name for Work) four Finnish celebrities sent job applications with their own CVs using typical Roma names. None of them received positive feedback (Deaconess Applied University of Helsinki, 2018).

Finally, there might also be some characteristics in Roma culture, which makes the adaptation to the overall socio-economic chance and new labour markets difficult. Over $40 \%$ of Roma respondents to Joronen's and Kruskopf's (2014; cf. Vesanen, 1999) study found that some features in the Finnish Roma culture are dysfunctional to Roma life, which may also reflect on the labour market status or performance. The features pointed out referred to decision-making, women's role, and general moral ideas (e.g. on cleanliness, chastity). Observing the national Roma dress code also seems to create problems in the Finnish labour market (Jauhola, Ärling, Luukkonen \& Oosi, 2019). 


\section{Research theme, data and methods}

We have now outlined and commented the situation of the Finnish Roma utilizing Messing's (2014a) description of factors contributing to low paid employment rate of Roma. In this article, we want to assess the above points made by Messing by means of recent Finnish data in order to confirm or develop them further or refute them. We aim (1) to describe the participation in paid work for Finnish Roma men and women and 2) to test the association between selected explanatory factors and paid work among the Finnish Roma. Explanatory factors are 1) education and language skills 2) cultural factors such as Roma language skills, living in Roma culture and Roma clothing and 3) perceived unjust treatment by the police and in public places.

This study uses data from the Finnish Roma Well-being Study, carried out by the Finnish Institute for Health and Welfare in 2017 and 2018 (Weiste-Paakkanen \& al., 2018). Data collection was prepared in detail, piloted in 2013, the national Roma community was involved with the research process from the very onset; there also was an information campaign on the study. A random sample was not able to be collected due to the constraints of the national legislation, thus the respondents were identified by a snowball method, which is rather a typical procedure in Roma research (cf. Messing, 2014b). The Finnish Roma Well-being Study focussed on health, wellbeing and social participation, and it included short and long versions of the structured interview or the self-filled questionnaire, and clinical health examination; thus, participation in the labour market and employment experience were not a key topic of the study.

In this study, the selection of the target group was based on selfidentification, since a random sample of an ethnic minority is not possible to obtain due to the Finnish Personal Data Act (523/1999, §6). According to Messing (2014b), it is often not possible to compose a representative sample of the Roma, and in many cases Roma identity is not 'binary': the Roma often have multiple identities. In Finland, the Roma cannot be studied in the context of major population surveys either, since the number of the Roma in Finland is, although not exactly known, rather small. The number of Roma immigrants to Finland has until now been insignificant and they were not included in the Finnish Roma Well-being Study. For a 
non-representative sample, according to Messing (2014b) settlement-based strategies have often been utilized, but there is no geographical segregation of Roma in Finland, and these strategies do not work.

The strength of this study is the unique data that utilized a culturesensitive and participatory study design (CBPR). In CBPR approach, community members and academic researchers work in partnership in each step of the research process to maximize the input from the community members (Mohammed, Walters, Lamarr \& Fryberg, 2010; Israel, Schulz, Parker, Becker \& Guzman, 1998). This article brings also the first results on paid employment of the Finnish Roma. The results comply with and supplement earlier international e.g. FRA findings. The links between health and functional capacity with employment as well as the details of Roma work potentially capturing a wider set of informal and work-like activities would deserve more attention in further research in Finland as well as internationally.

Altogether 365 adults participated at least for one part of the study, and of them $61 \%$ were female. In this article, we have used the data collected by the questionnaires from a subset of the sample consisting of respondents in working age (18-64 years). This subset of the whole data consists of 84 male and 150 female respondents.

Ethical approval for the study was obtained from Coordinating Ethics Committee of the Helsinki University Hospital.

\section{Variables}

The key question concerning paid work and the variable used in the analyses was: 'Have you been in full-time or part-time paid work during the last 12 months?' Answer options were 'yes '/'no'.

Socio-economic background variables included age, which was classified into three groups: 18-29 years old'; '30-54 years old'; '55 years old and older'. We may call the group ' $30-54$ years' encompassing the key years of a person's work life, while in the younger age group studies and child bearing compete with participation in work, and in the older age group there are various early retirement schemes in Finland reducing the participation in work. Socio-economic background variables included also 
the highest obtained education ('primary level or lower'; 'secondary level or higher').

Self-assessed reading and writing skills (two separate questions) were assessed by two questions 1) 'Do you write Finnish/ Swedish?' and 2) 'Do you read Finnish/ Swedish?'. Answer options for both questions were rated by a five-item Likert-scale ranging from 1 'excellent' to 5 'poor'. In the analyses the options 1 and 2 were dichotomized 'good or excellent' and the options 3, 4 and 5 as 'poor'. These skills link with education.

Cultural factors included the questions 'Do you live in Roma culture' ('yes'/'no'), and 'Do you observe the traditional Roma dress code?' ('yes'/'no')'. We also asked: 'Do you speak Finnish Roma language? Answer options and the classification were the same as used in Finnish/Swedish reading skills.

Discrimination was measured by the experience of unjust treatment in public places (when shopping, in a restaurant etc.) during the past 12 months. There was also a supplementary question 'do you avoid some places because you are worried about your safety?' Answer options were in both cases 'yes'/'no'. Perceived unjust treatment in public service was measured by the question: 'Have you used the following services, or had contacts with these authorities during the past 12 months? If you have, how have you been treated by them?' In this article, we analyse only the experience with the police. The options for answering were $1=$ 'I have not used the service'; 2 = 'I have used the service, and I was treated well'; and $3=$ 'I have used the service, and I was treated unjust'. For the analysis of the article, a binary variable 'Unjust treatment in such services' was formed by assigning option 2 the value 'yes' and option 3 the value 'no'.

\section{Statistical analyses}

We described and analysed the participation in paid work by means of the above socio-demographic background variables, self-assessed reading and writing skills, cultural factors and perceived unjust treatment or discrimination. We carried out the analyses separately for men and women as well as for the whole data. By the logistic regression, we tested the association between paid work and other variables for each variable 
separately. The odds ratios (OR) and corresponding 95\% confidence intervals $(95 \% \mathrm{CI})$ were calculated and are shown in the tables.

The data was weighted by gender and age (5-year age groups) to match the general population of Finland on 31 December 2017. All analyses were carried out using the SAS 9.4 statistical software.

\section{Results}

The description of the studied population is in Table I. Of the men $36 \%$ and of the female $40 \%$ had been in paid work during the past 12 months. Altogether $41 \%$ of the respondents were 30-54 years old, and the highest paid employment rate was in this age bracket, where $44 \%$ of men and $56 \%$ of women were in paid work. The paid employment rate is highest in the same age bracket also for all Finnish work force: among younger people, participation in education and training lowers the paid employment rate, while in the age bracket of 55+ years, various early retirement schemes, also based on disability, have a similar impact.

Altogether $44 \%$ of the male and $42 \%$ of the female respondent had secondary or higher education. Approximately three fourths of the respondents estimated they had good or excellent reading and writing skills. Most Roma (73\%) lived in Roma culture fully and always also observed the Roma dress code. However, only a small minority had good or excellent skills in the Roma language: $16 \%$ of the men and $9 \%$ of the women. Most respondents $-50 \%$ of the men and $55 \%$ of the women - had experienced unjust treatment in public (when shopping, in a restaurant etc.) i.e. public discrimination during the past 12 months. Unjust treatment by the police was rather common, experienced by $30 \%$ of the respondent men and $22 \%$ of women. Altogether $25 \%$ of men and $27 \%$ of women avoided certain places because they were worried about safety.

The association between paid work, education, skills, cultural factors and discrimination or unjust treatment experience, analysed for men and women as well as for the whole data by logistic regression, is in Table II.

The respondents aged 30-54 years had higher odds $(\mathrm{OR}=2.28(\mathrm{p}<0.1)$ for paid work than those who were younger or older. The result was somewhat surprisingly due to the results of the female subgroup and its higher paid employment rate in this age bracket. 
10 Mannila, et al. - Participation in paid employment Finnish Roma

The Roma men and women with a secondary or higher level of education were more likely to be in paid work (men: $\mathrm{OR}=2.75 ; \mathrm{p}=0.04$ and women: $\mathrm{OR}=4.29 ; \mathrm{p}<0.01)$ than those with primary or lower level of education. Self-assessed good or excellent reading skills associated even stronger with paid work among men $(\mathrm{OR}=3.83 ; \mathrm{p}<0.01)$ and women $(\mathrm{OR}=9.27 ; \mathrm{p}<0.01)$, but self-assessed writing skills associated only for women $(\mathrm{OR}=6.31 ; \mathrm{p}<0.01)$.

Table 1

Descriptive statistics of the research data, \% and weighted \%).

\begin{tabular}{|c|c|c|c|c|}
\hline \multirow{2}{*}{ INDICATOR } & \multirow{2}{*}{$\begin{array}{c}\text { Description } \\
\% \\
\text { (weighted \%) }\end{array}$} & \multirow{2}{*}{$\begin{array}{c}\text { All } \\
(\mathbf{n}=\mathbf{2 3 4}) \\
\% \\
\text { (weighted \%) }\end{array}$} & \multirow{2}{*}{$\begin{array}{c}\text { Men } \\
(\mathbf{n}=\mathbf{8 4}) \\
\% \\
\text { (weighted \%) }\end{array}$} & \multirow{2}{*}{$\begin{array}{c}\text { Women } \\
(\mathbf{n}=\mathbf{1 5 0}) \\
\% \\
\text { (weighted \%) }\end{array}$} \\
\hline & & & & \\
\hline \multirow{3}{*}{ Age } & $18-29$ years & $30(24)$ & $31(25)$ & $29(24)$ \\
\hline & $30-54$ years & $45(53)$ & $44(53)$ & $46(52)$ \\
\hline & $55-64$ years & $25(23)$ & $25(22)$ & $25(24)$ \\
\hline Education & $\begin{array}{c}\text { secondary level / } \\
\text { higher }\end{array}$ & $43(44)$ & $44(45)$ & $42(43)$ \\
\hline Reading skills & good / excellent & $77(75)$ & $68(68)$ & $82(81)$ \\
\hline Writing skills & good / excellent & $75(72)$ & $64(66)$ & $81(78)$ \\
\hline $\begin{array}{l}\text { Roma } \\
\text { language }\end{array}$ & good / excellent & $12(12)$ & $16(15)$ & $9(9)$ \\
\hline Roma culture & fully & $73(75)$ & $71(72)$ & $75(77)$ \\
\hline $\begin{array}{l}\text { Roma dress } \\
\text { code }\end{array}$ & always & $73(74)$ & $71(72)$ & $74(77)$ \\
\hline $\begin{array}{l}\text { Public } \\
\text { discrimination }\end{array}$ & $\begin{array}{l}\text { yes during } 12 \\
\text { months }\end{array}$ & $53(53)$ & $50(49)$ & $55(46)$ \\
\hline $\begin{array}{l}\text { Police unjust } \\
\text { treatment }\end{array}$ & $\begin{array}{l}\text { yes during past } 12 \\
\text { months }\end{array}$ & $26(26)$ & $30(29)$ & $22(23)$ \\
\hline
\end{tabular}


The respondents who lived fully in Roma culture were less likely to be in paid work $(\mathrm{OR}=2.22 ; \mathrm{p}<0.02)$ than those who lived in Roma culture partly or not at all. However, the link was not found in male or female subsets, probably related to the smaller sizes of these subsets. Those women who complied with the Roma dress code sometimes or never were more likely to be in paid work than those who always wore Roma clothes $(\mathrm{OR}=3.17$; $\mathrm{p}<0.02)$. In the male sub-group there was no link between Roma dress code and paid work: the Finnish Roma dress code for men is not as strict as for women, although new code variants for women are also developing.

Public discrimination as well as by the police as measured in the questionnaire were not associated with the paid work.

\section{Discussion}

This study described participation in paid work among the Finnish Roma men and women and analysed some factors potentially influencing it. According to the results, those aged 30-54 years had the highest employment rate $(45 \%)$ in our research group, but the employment rate of the same age group in the total Finnish population is much higher (77\%) (SVT, 2018).

These results are in line with many European studies showing that the employment rate among the Roma is often lower as compared to whole population. The relatively high employment rate of Finnish Roma women as compared to that of men - although the difference was not statistically significant - may be due to the traditional Nordic family model, where both husbands and wives are breadwinners of the family.

For Finland, it is also possible that some special employment schemes are more favourable to female than to male jobseekers. It would be useful to study the position of Roma men and women in the Finnish labour market more in detail. Additionally, since it has not been possible to assess the significance of informal work, there might be gender-specific differences, although informal work in general seems to be more typical of women than men (FRA, 2019).

The Finnish Roma men and women with a higher level of education were more likely in paid work, and those with good or excellent reading skills were more likely in paid work. Good writing skills associated with 
paid work only with the women. This result pointing out the importance of skills is rather typical of Roma research in general (cf. Brozovicova, Fabo, Kahanec \& Messing, 2012) and low education level is a major labour market handicap in developed countries in general (for Finland, e.g. Aho and Mäkiaho, 2016). This was not the case, when general education level of the population was low. Results from the Finnish Roma Well-being Study shows that the education level of the Finnish Roma is lower than that of the whole population, in compliance with international findings on Roma education level (Martelin, Kuusio \& Weiste- Paakkanen, 2018; FRA, 2018c: Kunac \& al., 2018). However, in Finland there is a generational difference (Martelin \& al., 2018). This may be due to a major reform in the Finnish basic education in the 1970s, bearing a positive impact also on the Roma children. The importance of education is shown, too by our findings, all respondents with a high school education or more had paid work experience.

Living in Roma culture associated for all and observing the Roma dress code for women negatively with paid work. The interrelation can most easily interpreted showing indirectly the impact of discrimination against the Roma, highly typical of the Finnish society as described above.

There was no link between discrimination experience and paid work, but this cannot be interpreted to show that discrimination does not play any role in the low paid employment rate of the Finnish Roma. The results point out the multifarious interrelation between discrimination and employment. We were not able to assess the discrimination against Roma in recruitment, most common in Finland well as in other European countries (European Commission, 2019; cf. ENAR, 2017; FRA, 2018c). Additionally, we also found that those with an experience of unjust treatment in public avoid twice more often than others certain places in fear of unsafety. This evasive behaviour also may complicate participation in the labour market indirectly. Paid work may also link with higher risk of unjust treatment for the Roma, due to increased contacts with the majority population. 
Table 2

The association of the explanatory factors with paid work by logistic regression (odds ratios (OR), $95 \%$ confidence intervals (CI), p-values.)

\begin{tabular}{|c|c|c|c|c|c|c|c|c|c|}
\hline \multirow{2}{*}{ INDICATOR } & \multicolumn{3}{|c|}{ All $(n=233)$} & \multicolumn{3}{|c|}{ Males $(n=84)$} & \multicolumn{3}{|c|}{ Females $(n=149)$} \\
\hline & $O R$ & $95 \%$ (C.I.) & $p$-value & $O R$ & $95 \%$ (C.I.) & $p$-value & $O R$ & $95 \%$ (C.I.) & $p$-value \\
\hline Age $18-29$ years & 1 & & & 1 & & & 1 & & \\
\hline Age $30-54$ years & 2.28 & $1.06-4.92$ & $0.035^{*}$ & 1.49 & $0.53-4.24$ & 0.451 & 3.61 & $1.15-11.35$ & $0.028^{*}$ \\
\hline Age $55-64$ years & 0.91 & $0.35-2.36$ & 0.838 & 0.60 & $0.15-2.36$ & 0.465 & 1.39 & $0.36-5.52$ & 0.639 \\
\hline \multicolumn{10}{|l|}{ Education } \\
\hline primary level or lower & 1 & & & 1 & & & 1 & & \\
\hline secondary level / higher & 3.39 & $1.74-6.62$ & $0.000^{* * * *}$ & 2.75 & $1.07-7.10$ & $0.037^{*}$ & 4.29 & $1.65-11.13$ & $0.003 * *$ \\
\hline \multicolumn{10}{|l|}{ Reading skills } \\
\hline poor / moderate & 1 & & & 1 & & & 1 & & \\
\hline good / excellent & 5.22 & $2.03-13.37$ & $0.001 * * *$ & 3.83 & $1.16-2.65$ & $0.028^{*}$ & 9.27 & $1.93-44.62$ & $0.006 * *$ \\
\hline \multicolumn{10}{|l|}{ Writing skills } \\
\hline poor / moderate & 1 & & & 1 & & & 1 & & \\
\hline good / excellent & 3.60 & $1.60-8.12$ & $0.002 * *$ & 2.58 & $0.92-7.19$ & 0.071 & 6.31 & $1.59-25.11$ & $0.009^{* *}$ \\
\hline \multicolumn{10}{|l|}{ Roma language } \\
\hline poor / moderate & 1 & & & 1 & & & 1 & & \\
\hline good/ excellent & 1.11 & $0.44-2.81$ & 0.826 & 1.27 & $0.40-4.00$ & 0.682 & 0.80 & $0.16-3.91$ & 0.779 \\
\hline
\end{tabular}


14 Mannila, et al. - Participation in paid employment Finnish Roma

\begin{tabular}{|c|c|c|c|c|c|c|c|c|c|}
\hline \multirow{2}{*}{ INDICATOR } & \multicolumn{3}{|c|}{ All $(n=233)$} & \multicolumn{3}{|c|}{ Males $(n=84)$} & \multicolumn{3}{|c|}{ Females $(n=149)$} \\
\hline & OR & 95\% (C.I.) & p-value & $O R$ & 95\% (C.I.) & p-value & $O R$ & 95\% (C.I.) & $p$-value \\
\hline \multicolumn{10}{|l|}{ Roma culture } \\
\hline fully & 1 & & & 1 & & & 1 & & \\
\hline partly / not at all & 2.22 & $1.18-4.40$ & $0.023 *$ & 1.99 & $0.79-5.05$ & 0.147 & 2.57 & $0.92-7.17$ & 0.072 \\
\hline \multicolumn{10}{|l|}{ Roma dress code } \\
\hline always & 1 & & & 1 & & & 1 & & \\
\hline sometimes / never & 2.09 & $1.05-4.17$ & $0.036^{*}$ & 1.34 & $0.53-3.42$ & 0.539 & 3.70 & $1.27-10.78$ & $0.017 *$ \\
\hline \multicolumn{10}{|l|}{ Public discrimination } \\
\hline no & 1 & & & 1 & & & 1 & & \\
\hline yes & 1.32 & $0.70-2.50$ & 0.389 & 1.79 & $0.74-4.34$ & 0.197 & 0.93 & $0.36-2.40$ & 0.886 \\
\hline \multicolumn{10}{|l|}{ Police unjust treatment } \\
\hline no & 1 & & & 1 & & & 1 & & \\
\hline yes & 1.37 & $0.50-3.79$ & 0.545 & 0.77 & $0.19-3.04$ & 0.707 & 2.50 & $0.48-13.06$ & 0.276 \\
\hline
\end{tabular}


The results confirm the importance of education as a key to successful paid employment in Finland similarly to the findings from other EU countries. Due to the limitations of the data, they do not shed much light on the mechanisms between discrimination experience and paid work. The role of Roma culture deserves attention. Strong Roma culture protects the community (cf. Crowe, 2007), but a closer look at the negative statistical association between living in Roma culture and paid work would be needed.

Following practical implications for state and local governments as well as the Roma organizations were outlined by the Finnish Roma Well-being Study, with the help of Roma advisors of the study (Weiste-Paakkanen \& al., 2018). They seem relevant also here:

- Supporting education and employment, fighting against discrimination in particular in education and training; encouraging the Roma to study for higher education are important for the inclusion of the Roma in paid employment.

- Reducing discrimination by informing about Roma culture and increasing natural everyday encounters as well as actively addressing grievances would be productive to supporting the recruitment of Roma. Focusing increasingly on good practices and highlighting success stories of Roma persons would be an innovative approach not often utilized.

- The Roma community's own resources, such as mutual assistance and participation need strengthening, supporting and exploiting.

There is important historical and cultural focus on the Roma community in Finland, but the information related to the living conditions of the Roma is still rather scarce and more research into them would be welcome.

Finnish National Roma Policy 2018-22 includes among its key focuses strengthening of Roma participation in all forms and levels education and training as well as promotion of Roma skills, employment, entrepreneurship and integration in the labour market. The means for achieving this are similar to those available for the general population and emphasise information dissemination and training among e.g. civil servants, educational institutions, employers and representatives of the Roma 
community (Finnish Ministry of Social Affairs and Health, 2018). Due to the small size of the Roma community, the mainstream employment policy, although "tailored services" are enhanced, is often not sensitive enough for the needs of Roma jobseekers (cf. Jauhola \& al., 2019). Finnish national Roma policy is in compliance with the EU Framework for National Roma Integration Strategies, but a great deal remains to be done as shown e.g. by the latest discrimination survey by the European Commission (2019).

Policy-wise focus on formal employment necessitates activation policies rather than calls for social inclusion (Messing 2014b): the former approach lays emphasis on employment policy, the latter one lays it on social policy. Both approaches would be relevant for a better Roma integration in the Finnish labour market and paid employment.

\section{References}

Aho, S. and Mäkiaho, A. (2016). "Krooninen työttömyys". Valtioneuvoston selvitys- ja tutkimustoiminnan julkaisusarja 20/ 2016, Helsinki:

Prime Minister's Office.

https://tietokayttoon.fi/documents/10616/2009122/20_Krooninen+ty ott\%C3\%B6myys.pdf/d216f5a7-1ef4-48ee-bff1-

d26bdef075bd/20_Krooninen+tyott\%C3\%B6myys.pdf?version=1.0.

(Chronic Unemployment, in Finnish.)

Anttonen, R. (2008). "Trust Formation and Experiences of Prejudice and

Discrimination of Roma Entrepreneurs in Finland". Journal of

Enterprising Communities: People and Places in the Global

Economy, 2, 2. https://doi: 10.1108/17506200810879952.

Berlin, J. (2015). Assimilated Individuals and Segregated Communities.

Kuopio: Publications of the University of Eastern Finland,

Dissertations in Social Sciences and Business No. 101.

https://epublications.uef.fi/pub/urn_isbn_978-952-61-1737-

9/urn_isbn_978-952-61-1737-9.pdf.

Brozovicova, K., Fabo, B., Kahanec, M. \& Messing, V. (2012). "Overview of the labour market situation of low-educated and Roma population and regulations affecting their employment". NEUJOBS State of the Art Report No. D19.1. Budapest: Center of Policy Studies, Central European University. 
http://conference.iza.org/conference_files/neujobs_2014/kahanec_m2 268.pdf.

Council of Europe (2012). Human rights of Roma and Travellers in

Europe. Strasbourg: Council of Europe, Commissioner for Human

Rights. https://rm.coe.int/the-human-rights-of-roma-and-travellersin-europe/168079b434.

Clark, C. (2002). "Not just lucky white Heather and clothes pegs: Putting European Gypsy and Traveller economic niches in context". In S.

Fenton \& H. Bradley (Eds.), Ethnicity and Economy. London:

Palgrave Macmillan.

Crowe, D.M. (2007). A History of the Gypsies of Eastern Europe and Russia. New York: Palgrave Macmillan.

Deaconess Applied University of Helsinki (2018). "Palkkaisitko?

Romanien osallisuus", 28.11.2018. https://peda.net/diak/romanienosallisuus. (Would You Hire? The Participation of the Roma, in Finnish.)

ENAR (European Network Agains Racism) (2017). Racism and

Discrimination in Employment in Europe 2013 - 2017, Shadow

Report. Brussels: ENAR. https://www.enar-

eu.org/IMG/pdf/20107_shadowreport_2016x2017_long_v8_hr.pdf. Esping-Andersen, G. (1990). The Three Worlds of Welfare Capitalism.

London: Sage.

Esping-Andersen, G. (1996). Welfare States in Transition, National

Adaptations in Global Economics. London: Sage.

European Commission (2019). Discrimination in the European Union,

Special Eurobarometer 493.

https://data.europa.eu/euodp/fi/data/dataset/S2251_91_4_493_ENG. Eurostat (2019). Youth Unemployment.

https://ec.europa.eu/eurostat/statistics-

explained/index.php?title=Youth_unemployment\&oldid=427759\#Yo ung_persons.27_participation_in_the_labour_market.

Finnish Ministry of Social Affairs and Health (2004) Finland's Romani

People. Brochures of the Finnish Ministry of Social Affairs and Health 2004: 2.

https://julkaisut.valtioneuvosto.fi/bitstream/handle/10024/70194/Es2 00402eng.pdf? sequence $=1$. 
18 Mannila, et al. - Participation in paid employment Finnish Roma

Finnish Ministry of Social Affairs and Health (2018) Finnish National Roma Policy (edited by Henna Huttu), Publications of the Finnish Ministry of Social Affairs and Health 3/2018. http://urn.fi/URN:ISBN:978-952-00-3916-5.

FRA (European Union Agency for Fundamental Rights) (2018a). Second European Union Minorities and Discrimination Survey, A persistent concern: anti-Gypsyism as a barrier to Roma inclusion, EU-MIDIS II. Luxembourg: Publications Office of the European Union. https://fra.europa.eu/sites/default/files/fra_uploads/fra-2018-antigypsyism-barrier-roma-inclusion_en.pdf.

FRA (European Union Agency for Fundamental Rights) (2018b). Second European Union Minorities and Discrimination Survey, Roma Selected findings, EU-MIDIS II. Luxembourg: Publications Office of the European Union, Luxembourg. https://fra.europa.eu/sites/default/files/fra_uploads/fra-2017-eumidis-ii-main-results_en.pdf.

FRA (European Union Agency for Fundamental Rights) (2018c). Second European Union Minorities and Discrimination Survey, Transition from education to employment of young Roma in nine EU Member States, EU-MIDIS II. Luxembourg: Publications Office of the European Union.

https://fra.europa.eu/sites/default/files/fra_uploads/fra-2018-eumidis-ii-roma-transition-education-employment_en.pdf.

FRA (European Union Agency for Fundamental Rights) (2019). Second European Union Minorities and Discrimination Survey, Roma women in nine EU Member States, EU-MIDIS II. Luxembourg: Publications Office of the European Union.

https://fra.europa.eu/sites/default/files/fra_uploads/fra-2019-euminorities-survey-roma-women_en.pdf.

FRA (European Union for Fundamental Rights (2012). Poverty and Employment, The Situation of Roma in 11 EU Member States, Roma Survey - Data in Focus. Luxembourg: Publications Office of the European Union.

https://fra.europa.eu/sites/default/files/fra_uploads/fra-2014-romasurvey-dif-employment-1_en.pdf. 
Frazer, N., Gutiérrez, R. \& Pena-Casas, R. (2011), Working Poor in Europe, A Comparative Approach, Basingstoke: Palgrave Macmillan.

Granqvist. K. (2020). Critical Evaluation of Romani Inclusion Strategies in Finland and Sweden. Journal of Contemporary European Studies, https://doi.org/10.1080/14782804.2020.1801394.

ILO (International Labour Organization) (1993). Resolution concerning the International Classification of Status in Employment (ICSE).

https://www.ilo.org/global/statistics-and-databases/standards-andguidelines/resolutions-adopted-by-international-conferences-oflabour-statisticians/WCMS_087562/lang--en/index.htm.

Israel, B.A., Schulz, A., Parker, E., Becker, A., Allen, A. \& Guzman, J. (2005). Critical ssues in developing and following community based participatory research principles. In M. Minkler \& N. Wallerstein (Eds.), Community-based Participatory Research for Health (pp. 53 76). San Francisco. Jossey Bass.

Jauhola, L., Ärling, M., Karinen, R., Luukkonen, T. \& Oosi, O. (2019).

"Romanien työllisyys, yrittäjyys ja työmarkkinoille integroituminen". Työ- ja elinkeinoministeriön julkaisuja, Työelämä 2019: 58, Helsinki: (Finnish) Ministry of Employment and the Economy. http://julkaisut.valtioneuvosto.fi/bitstream/handle/10024/161893/TE M_2019_58.pdf. (Employment, Entrepreneurship and Integration in the Labour Market of the Roma, in Finnish.)

Joronen, M. \& Kruskopf, P. (2014). "Erilaisena arjessa. Selvitys romanien syrjintäkokemuksista". Helsinki: Vähemmistövaltuutetun julkaisusarja 15.

https://www.syrjinta.fi/documents/10181/10850/52878_romaniselvit ys_verkkoon+(1).pdf/584516fc-d3a7-4f88-8ecc-c8b2271ebf41.

(Different in Everyday Life - A Survey into the Discrimination Experience of the Roma, in Finnish.)

Keskinen, S. (2019). Intra-Nordic Differences, Colonial/Racial Histories and National Narratives: Rewriting Finnish History. Scandinavian Studies, 91, 1 - 2, 163 - 181, https://doi.org/10.5406/scanstud.91.12.0163 .

Kunac, S., Klasnić, M. \& Lalić, S. (2018). Roma Inclusion in the Croatian Society: A Baseline Data Study. Zagreb: Centre of Peace Studies. 
Kurkela, V. (2003). Eriytyvien yleisöjen aika. In P. Jalkanen \& V. Kurkela, Populaarimusiikki, Suomen musiikin historia (pp. 462 - 618).

Helsinki: Werner Söderström. (Time of Differentiating Audiences, in: Popular Music, History of Finnish Music, in Finnish.)

Lähteenmäki-Smith, K. (2011). Promoting Social Inclusion of Roma, A

Study of National Policies. Helsinki: Ramboll Management

Consulting.

Martelin, T., Kuusio, H. \& Weiste-Paakkanen, A. (2018). Koulutus, työllisyys ja toimeentulo. In A. Weiste-Paakkanen, R. Lämsä \& H. Kuusio (Eds.), Suomen romaniväestön osallisuus ja hyvinvointi. Romanien hyvinvointitutkimus Roosan perustulokset 2017 - 2018, THL Raportti 15/2018 (pp. 29 - 39). Helsinki: Institute for Health and Welfare. http://urn.fi/URN:ISBN:978-952-343-246-8.

(Education, Employment and Subsistence, in Finnish.)

Messing, V. (2014a). "Patterns of Roma employment in Europe".

NEUJOBS Policy Brief No. D19.4 March 2014. Budapest: Center of

Policy Studies, Central European University.

https://www.academia.edu/9977725/Patterns_of_Roma_employment in_Europe.

Messing, V. (2014b). "Methodological puzzles of surveying Roma/ Gypsy populations", Ethnicities, 14(6), $811-829$.

https://www.researchgate.net/publication/285293447_Methodologica 1_puzzles_of_surveying_RomaGypsy_populations.

Mohammed, S.A., Walters, K.L., Lamarr, J. \& Fryberg, S. (2012). "Finding Middle Ground: Negotiating University and Tribal Community Interests in Community-based Participatory Research". Nursing Inquiry, 19, 116 - 127.

Nordberg, C. (2005). "Integrating a Traditional Minority into a Nordic Society: Elite Discourse on the Finnish Roma". Social Work \& Society, 3, 2, $158-173$. https://www.socwork.net/sws/article/view/196/256.

Paulus, I. (1996). Suomen romaniväestön asuntotilanne 1990-luvun puolivälissä. Suomen ympäristö 46. Helsinki: (Finnish) Ministry of Environment. (Housing of the Finnish Roma Population in mid 1990s, in Finnish.) 
Petrova, D. (2004). The Roma: Between a Myth and the Future. Budapest: European Roma Rights Centre. http://www.errc.irg/cikk.php?cikk=1844.

Rajala, S. \& Blomerus, S. (2015). "Katsaus aikuisten romanien koulutustaustoihin". Katsaukset ja selvitykset 2015: 8, Helsinki: Board of Education. https://www.oph.fi/sites/default/files/documents/175254_katsaus_aik uisten_romanien_koulutustaustoihin_0.pdf. (Review of the Educational Background of Adult Roma, in Finnish.)

Rajala, S., Salonen, M., Blomerus, S. \& Nissilä, L. (2011).

"Romanioppilaiden perusopetuksen tilannekatsaus 2010 - 11 ja toimenpide-ehdotukset”. Helsinki: Board of Education.

https://www.oph.fi/sites/default/files/documents/140023_romanioppi laiden_perusopetuksen_tilannekatsaus_2010-2011_ja_toimenpideehdotukset.pdf. (Review of the Situation of Roma pupils in Basic Education, in Finnish.)

Ram, M. H. (2014). "Europeanized Hypocrisy: Roma Inclusion and Exclusion in Central and Eastern Europe". Journal on Ethnopolitics and Minority Issues in Europe, 13, 3, 15 - 44.

https://www.ecmi.de/fileadmin/downloads/publications/JEMIE/2014/ Ram.pdf.

Robayo-Abril, M. \& Millán, N. (2019). Breaking the Cycle of Roma Exclusion in the Western Balkans. Washington: World Bank Group. http://documents.worldbank.org/curated/en/642861552321695392/pd f/Breaking-the-Cycle-of-Roma-Exclusion-in-the-WesternBalkans.pdf.

Rosenfield, E. (2010). "Combating Discrimination against the Roma in Europe: Why Current Strategies Aren't Working and What Can Be Done". Topical Research Digest: Minority Rights.

https://www.du.edu/korbel/hrhw/researchdigest/minority/Roma.pdf. Saaritsa, S. (2008). "Informal Transfers, Men, Women and Children:

Family Economy and Informal Social Security in Early 20th Century Finnish Households". History of the Family, 13(3), 315 - 331. https://doi.org/10.1016/j.hisfam.2008.08.003.

SVT (Suomen virallinen tilasto) (2018), Työvoimatutkimus, Aikasarjatiedot 2009 - 2018 2018, 2, Työllisyys ja työttömyys vuonna 2018, Helsinki: 
22 Mannila, et al. - Participation in paid employment Finnish Roma

Statistics Finland.

http://www.stat.fi/til/tyti/2018/13/tyti_2018_13_2019-04-

11_kat_002_fi.html. (Labour Force Survey, Time Series 2009 2018, in Finnish.)

Syrjä, H. \& Valtakari, M. (2008). "Romanien pitkä matka työmarkkinoille". Helsinki: (Finnish) Ministry of Employment and the Economy, Työja yrittäjyys 22/2008. https://docplayer.fi/16551285-Romanienpitka-matka-tyon-markkinoille-tutkimus-romanien-tyomarkkinoillesijoittumisen-edistamisesta.html. (The Roma Long Way to the Labour Market, in Finnish.)

Tervonen, M. (2014), Romanit ja suuri muutos. In P. Pulma P (Ed.) Suomen romanien historia (pp. 166 - 197). Helsinki: Suomalaisen

kirjallisuuden seura. (The Roma and the Great Change, in: History of the Finnish Roma, in Finnish.)

Törmä, S. \& Huotari, K. (2018). Romanien asumisen yhdenvertaisuuden seurantaselvitys. Raportteja 6/ 2018. Helsinki: (Finnish) Ministry of Environment. (Follow-up Study on Equality in Roma Housing, in Finnish.)

Vesanen, P. (1999). Romanikulttuurin piirteet heijastuvat asunnon järjestymiseen. Asu ja rakenna, 6, 9-12. (The characteristics of Roma culture reflect in access to housing, in Finnish.)

Vähätalo, K. (1998). Työttömyys ja suomalainen yhteiskunta. Tampere:

Gaudeamus. (Unemployment and Finnish Society, in Finnish.)

Weiste-Paakkanen, A., Lämsä, R. \& Kuusio, H. (2018), Suomen romaniväestön osallisuus ja hyvinvointi,, THL Raportti 15/2018. Helsinki: National Institute for Health and Welfare.

http://urn.fi/URN:ISBN:978-952-343-246-8. (Participation and Wellbeing of the Finnish Roma, in Finnish.) 
Simo Mannila (D.Pol.Sc, University of Helsinki, 1993), Adjunct Professor in Sociology at the University of Helsinki and Adjunct Professor in Social Policy at the University of Turku.

Anu E Castaneda (PhD, Psychology, 2010, University of Helsinki), Research Manager, with the Finnish Institute for Health and Welfare. She is also Adjunct Professor in Health and Clinical Psychology at the University of Helsinki.

Marianne Laalo (MScSoc, University of Helsinki), Guest Researcher, with the Finnish Institute for Health and Welfare.

Hannamaria Kuusio (PhD, Public Health, 2014, University of Helsinki), Research Manager, with the Finnish Institute for Health and Welfare.

Contact address: simo.mannila@luukku.com 